\title{
消費者の心をつかむトヨタ
}

\section{Toyota on a roll}

Nature Vol.435(1004)/23 June 2005

日本の工業技術革新への取り組み方は流行遅れかもしれないが、成果はきちんとあがっている。

日本の自動車メーカーであるトヨ夕自動車にとって、 2005 年は当たり年となった。同社の世界的収益が高水 準に達したことから、この 4 月に、奥田碩会長は、肥 大化した米国のライバル会社、フォードとゼネラルモー ターズが「若干息をつけるように」販売価格を引き上げ る可能性を示した。

自動車産業は、数十年前のように景気のけん引役を果 たしていないが、自動車は今でも個人消費のきわめて大 きな部分を占めている。この産業は伝統的に保守的なの だが、電子や材料、環境工学その他の分野での技術革新 が盛んになった。

自動車産業では、科学の基礎研究が、技術革新の数歩 先で行われるのが通常である。しかしトヨ夕は、名古屋 市近郊にある豊田中央研究所で、興味深いことを行って いる (Nature2005 年 6 月 23 日号 p.1026参照)。他の 分野と同じように、科学的知識が工業的に応用されるま での移行期間は短くなってきている。

これまでのトヨタの成功は、技術革新というよりもつ ねに工業的効率の改善であった。それでもトヨ夕の技術 は、過去 10 年で着実に進歩したのに対し、ライバルの 米国メーカーは過去の成功に満足してしまった。保守 的に設計された大型スポーツユーティリティー車 (SUV) の販売ブームが過ぎ去った今、米国の自動車メーカー は、突然厳しい現実に直面している。

今年の初め、米国自動車産業の将来的な事業見通し が暗転したために、信用調査機関は、フォードとゼネ ラルモーターズの一部の社債の格付けをジャンク ( 投資 不適格) 級に引き下げるという、両社にとって屈辱的な 決定をした。これが奥田会長の発言に結びついたよう
だ。同会長は米国自動車産業が新たな危機に見舞われる と、保護貿易主義が台頭してトヨ夕が損害をこうむる 可能性があると思ったのである。そして 6 月に入って、 ゼネラルモーターズは、北米の工場労㗢力の約 4 分の 1 に当たる 2 万 5000 人の人員削減計画を発表した。

抢そらくトヨ夕と米国のライバル会社との最も際立 つたちがいは、環境技術の発展に取り組む姿勢だったと いえよう。米国の大手自動車メーカーの幹部は、まるで パロディーを演じているかのようだった。彼らは、クリ ントン大統領が抒拐いに吹聴した新世代自動車共同開 発計画 (Partnership for a New Generation of Vehicles) によって、多額の補助金を受け取る見返りに規制緩和を 求め、開発計画への参加があたかも納税者の利益になる かのように振舞ったのだった。この計画は実施された が、すぐに消滅した。そして昨年、原油価格が青天井で 高騰したときに、準備ができていたのは、超低燃費の「八 イブリッド」車を発売した日本のトヨタ、ホンダであり、 ゼネラルモーターズやフォードではなかった。

科学技術や技術革新に対するトヨ夕の取り組みは、け っして奇抜なものとはいえない。奇抜なことはできない のだ。消費者の手元に届いたとき、製品がきちんと動か なけ机ばならないことを同社はわかっているのである。 トヨタの研究者やエンジニアは、カリフォルニアのシ リコンバレーがモデルとなるような現代の華やかな技 術革新パラダイムには当てはまらない。むしろ、彼らは 細心の注意を払い、会社に非常に忠実で、共同作業に基 づいた考方方をもち、目立たないようにすることに熱心 だ。これによって立派な成果があがって扔り、技術革新 の成功には、さまざまな形があることを示している。 